\title{
'PLUG FREE' CONNECTOR PLACEMENT MODIFICATION OF A BILAYER PATCH DEVICE IN MALE INDIRECT INGUINAL HERNIOPLASTY
}

\author{
Miroslav D. Ilicí ${ }^{1,2}$ and Srdjan S. Putnik ${ }^{2,3}$ \\ ${ }^{1}$ Clinical Department of Thoracic Surgery, Institute for Lung Diseases of Vojvodina, Sremska Kamenica; \\ ${ }^{2}$ University of Novi Sad, School of Medicine, Novi Sad; ${ }^{3}$ Department of General Surgery, \\ Vršac General Hospital, Vršac, Serbia
}

\begin{abstract}
SUMMARY - The bilayer patch device (Ethicon, Prolen Hernia System ${ }^{\circledR}$ ) for inguinal hernia repair has a connector that acts as a ,plug' in the internal inguinal ring. The position of this ,plug' component may be responsible for higher incidence of chronic pain and intestinal damage. We assumed that changing the position of the connector of a bilayer patch device $\left(\mathrm{PHS}^{\odot}\right)$ and placing it medially in Hesselbach triangle would contribute to lower incidence of chronic pain and would not result in intestinal damage, with good clinical outcome following indirect inguinal hernioplasty. This retrospective study included 73 patients with 76 indirect inguinal hernias, who underwent the procedure of modifying the position of the bilayer patch device in the 2005-2015 period. The mean age of the patients was 57 years. Three patients had early postoperative complications (3.95\%), two of which had postoperative seroma and one had postoperative pain. Three patients $(3.95 \%)$ had late postoperative complications. One patient $(1.32 \%)$ had chronic pain. There was one recurrence $(1.32 \%)$ and one patient (1.32\%) needed the mesh removed due to discomfort. The 'plug free' position of the connector of a bilayer patch device in patients with indirect inguinal hernioplasty is a safe procedure with low rate of chronic pain, no intestinal damage, and standard low recurrence.
\end{abstract}

Key words: Bilayer patch device; Connector; Indirect inguinal hernioplasty; Recurrence; Chronic pain

\section{Introduction}

In the description of the original technique for the placement of bilayer patch device (Ethicon, Prolen Hernia System ${ }^{\circledR}$, PHS), which is a three-dimensional double layer device, the connector of the PHS has a role of a 'plug in', which is positioned in internal inguinal ring, very close to the spermatic cord and in contact with the genital branch of genitofemoral nerve, ilioinguinal nerve, and sympathetic nerves (testicular plexus $)^{1,2}$. This 'plug' position in original PHS hernioplasty could account for $0.7 \%$ to $3.2 \%$ of chronic postoperative pain ${ }^{3,4}$. Furthermore, PHS hernioplasty has

Correspondence to: Prof. Miroslav Ilić, MD, PhD, Institute for Lung Diseases of Vojvodina, Put dr Goldmana 4, 21230 Sremska Kamenica, Serbia

E-mail:drmiroslavilic@gmail.com

Received February 4, 2016, accepted April 27, 2016 recently been associated with serious complications and damage to the large intestine due to contact with and erosion of bowel if the connector is placed through internal inguinal ring ${ }^{5,6}$.

In direct inguinal hernia, it is possible to place the connector of a bilayer patch device medially in Hesselbach triangle. In that position, the sublay part of the device covers from the inner side the entire inguinofemoral region and all the weak points, while onlay mesh stays above the spermatic cord as in the Lichtenstein repair ${ }^{7}$.

We assumed that connector position in Hesselbach triangle through a new incision on transverse fascia, in 'plug free' position and without a connector in internal inguinal ring, would result in lower incidence of chronic pain, no intestinal damage, and good clinical outcome for long term hernia repair. 


\section{Patients and Methods}

This retrospective study was carried out at a tertiary Clinical Department of Thoracic Surgery, Institute for Pulmonary Diseases of Vojvodina, Serbia. This Department is not a dedicated hernia center, and surgical ward is occupied with patients suffering from lung and esophageal cancer, as well as thoracic trauma patients. On a yearly basis, the number of hernia patients is very low. All these patients are of advanced age and with serious comorbidities, especially chronic obstructive disease, cardiac diseases, and diabetes. In the course of eleven years (2005-2015), we analyzed 73 male patients with indirect inguinal hernia, unilateral or bilateral, primary or recurrent, in whom we performed placement modification of the PHS mesh, with 'plug free' position of the connector in Hesselbach triangle, medially of lower epigastria vessels. We performed 'plug' PHS hernioplasty, regardless of whether they were primary or recurrent hernias.

All patients underwent 'plug free' PHS hernioplasty in general anesthesia, with standard antibiotic prophylaxis and anticoagulant therapy. The night following the operation, all patients received the same treatment for postoperative pain, i.e. intramuscular injections of nonsteroidal anti-inflammatory drug (NSAID). All patients were discharged from the hospital on the first postoperative day, while follow up was carried out seven days after the operation. Skin staples were removed on postoperative day ten. All events observed during that period were recorded as early postoperative complications. All patients had the option of calling the surgical ward or even the surgeon to complain. In each patient we analyzed the operative protocol, postoperative period, and early results of the operation. In June 2015, we conducted telephone interviews with all the patients and recorded their answers in a specially designed questionnaire, with particular emphasis on postoperative acute and chronic pain, late complications, and recurrences. One researcher conducted telephone interviews with the patients, none of whom stated anything that would suggest complications.

\section{Description of the 'plug free' PHS technique}

Skin incisions of $3 \mathrm{~cm}$ were opened in the inguinal region over inguinal canal subcutaneous tissue, Scarp fascia and oblique external muscle fascia (Fig. 1A). Af- ter identifying the nerves of the inguinal region, hernia sac was separated from the spermatic cord and pushed back in the preperitoneal space without resection (Figs. 1B and 1C). Lower epigastria vessels were identified and $1-\mathrm{cm}$ incisions were made through transverse fascia medially in Hesselbach triangle (Fig. 1D). Preperitoneal spaces were prepared with moist gauze (Fig. 1E), and the sublay patch of the device was stretched to cover internal inguinal ring from the posterior side (Fig. 1F). The connector was placed in the incision of transverse fascia in Hesselbach triangle (Fig. 1G). Onlay patch was opened from the longest axis in $\mathrm{Y}$ fashion for passing spermatic cord and sutured with non-absorbable suture (Figs. $1 \mathrm{H}$ and $1 \mathrm{I}$ ), very similar to the Lichtenstein technique, starting from the pubic tubercle, two sutures on internal oblique muscle avoiding iliohypogastric nerve, and with two sutures on the inguinal ligament of Poupart (Fig. 1J). Over onlay patch fascia of oblique external muscle were also closed with non-absorbable suture (Prolen 3-0) (Fig. 1K). Skin staplers were used to close the wound (Fig. 1L).

\section{Results}

During the period of eleven years, there were 73 patients with 76 indirect inguinal hernias. The frequency of operated patients is presented in Table 1 . There were three patients with bilateral indirect inguinal hernia, in whom we also performed bilateral 'plug free' PHS hernioplasty (Table 2). The same operation was performed in six patients with recurrent inguinal hernia.

The complications of 'plug free' PHS hernioplasty are presented in Table 3. During the postoperative period, seroma was found in two cases, and was evacuated together with removal of one or two skin staples, and prolonged bandaging gauze was necessary. One patient reported strong early postoperative pain during a period of two weeks, which was treated with orally administered NSAID. In one patient, recurrent indirect hernia occurred within 2 years after the operation, and the patient presented for second operation. After exploration of 'plug free' PHS, we found recurrence on dilated inguinal ring beyond onlay mesh. This situation was solved with two additional stitches with non-absorbable suture, without revision of the previous position of PHS device. 


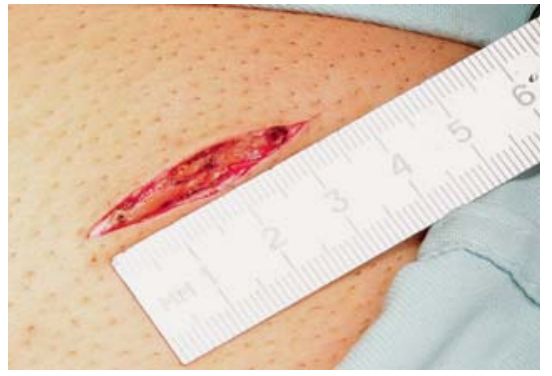

A) Skin incision in inguinal region

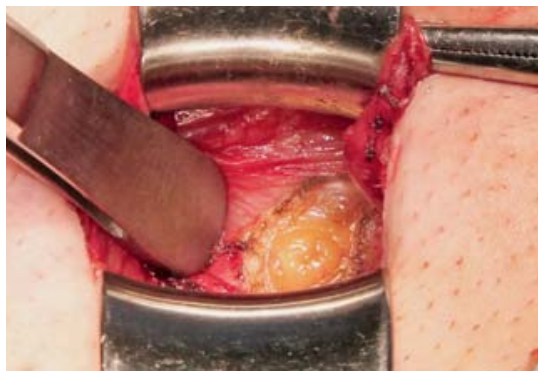

D) Incision in Hesselbach triangle medially of lower epigastria vessels

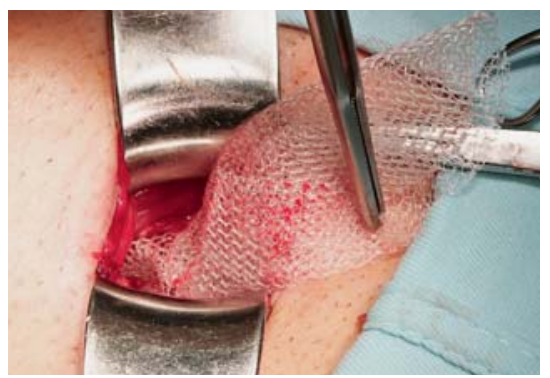

G) Position of the connector

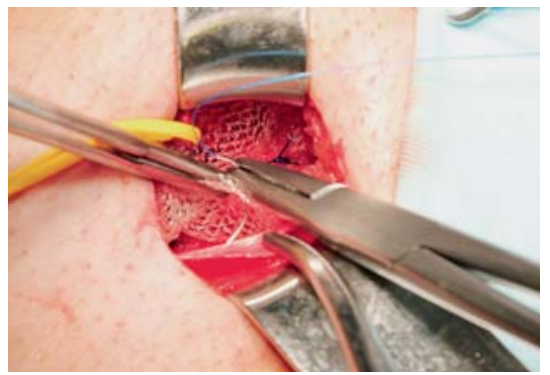

$J$ ) Sutures on the inguinal ligament of Poupart

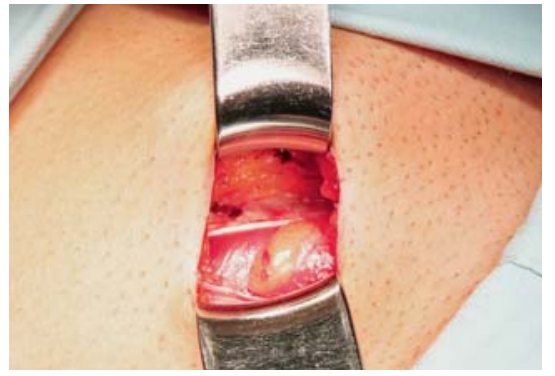

B) Indirect inguinal hernia

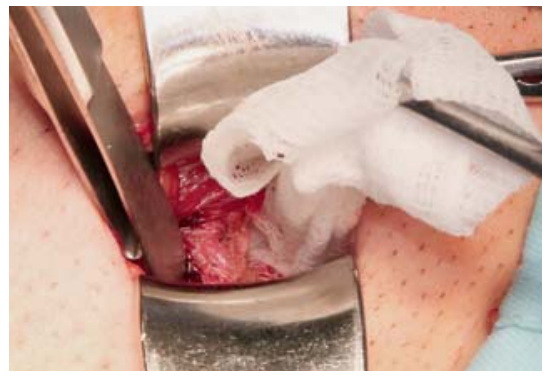

E) Preperitoneal space prepared with moist gauze

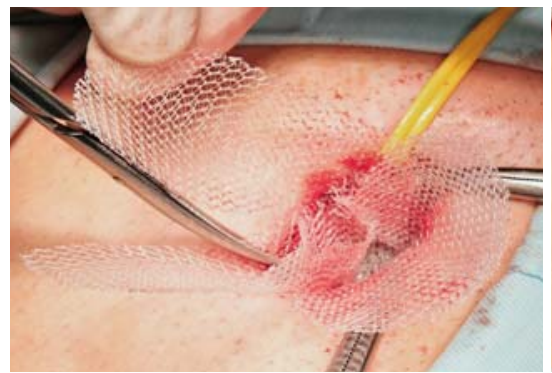

H) Opening onlay patch for passing spermatic cord

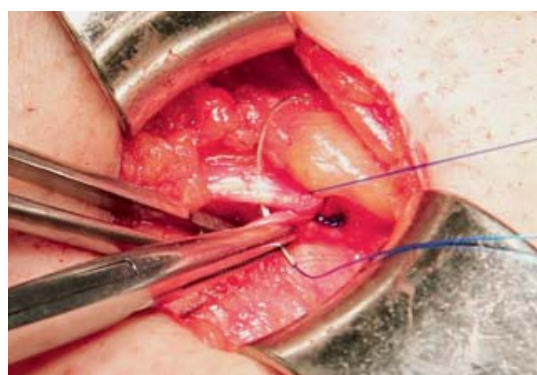

K) Closing fascia of oblique external muscle with non-absorbable suture

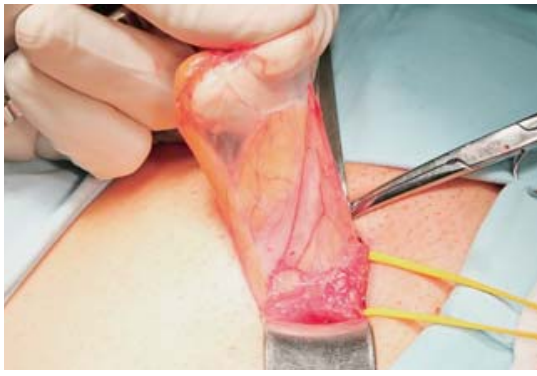

C) Hernia sac

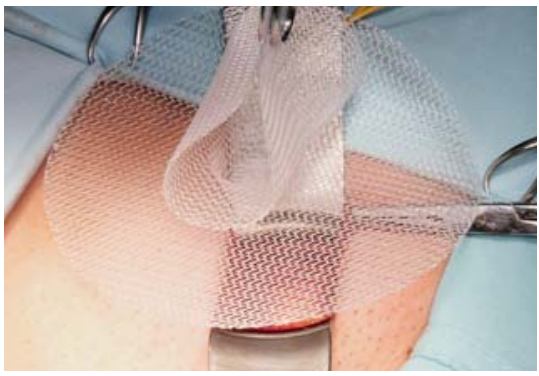

F) PHS extended

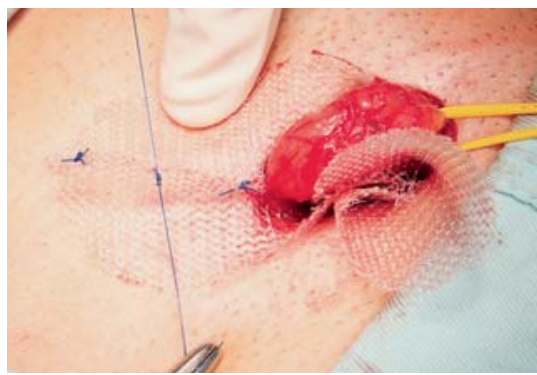

I) Sutured onlay patch with nonabsorbable suture

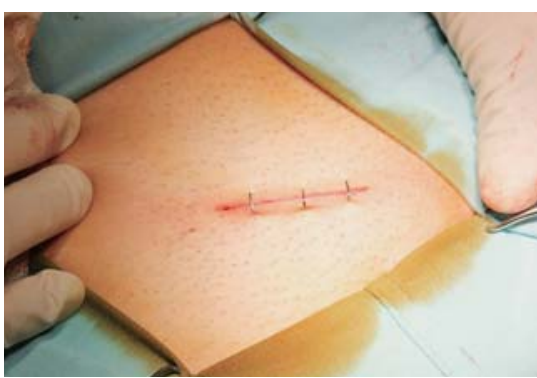

L) Closed wound with skin staplers

Fig. 1. Description of 'plug free' Prolen Hernia System ${ }^{\circledR}$ (PHS) technique: A) skin incision in inguinal region; $B)$ indirect inguinal hernia; $C$ ) hernia sac; D) incision in Hesselbach triangle medially of lower epigastria vessels; E) preperitoneal space prepared with moist gauze; F) PHS extended; G) position of the connector; H) opening onlay patch for passing spermatic cord; I) sutured onlay patch with non-absorbable suture; J) sutures on the inguinal ligament of Poupart; K) closing fascia of oblique external muscle with non-absorbable suture; $L$ ) closed wound with skin staplers. 
Table 1. Annual incidence of indirect inguinal hernia operation

\begin{tabular}{|l|c|c|}
\hline Year & Incidence & $\%$ \\
\hline 2005 & 8 & 11.0 \\
2006 & 8 & 11.0 \\
2007 & 5 & 6.8 \\
2008 & 6 & 8.2 \\
2009 & 4 & 5.5 \\
2010 & 3 & 4.1 \\
2011 & 8 & 11.0 \\
2012 & 7 & 9.6 \\
2013 & 7 & 9.6 \\
2014 & 13 & 17.8 \\
2015 & 4 & 5.5 \\
Total & 73 & 100.0 \\
\hline
\end{tabular}

Table 2. Characteristics of patients and indirect inguinal hernias

\begin{tabular}{|l|l|l|}
\hline \multicolumn{2}{|l|}{ Characteristic } & Value \\
\hline Number of patients & 73 \\
\hline Sex & Male & 73 \\
\hline Number of hernias & 76 \\
\hline Age (years) & Mean & 57.47 \\
\cline { 2 - 3 } & Range & $27-91$ \\
\hline \multirow{3}{*}{ Side of hernia } & Right & $41(53.95 \%)$ \\
\cline { 2 - 3 } & Left & $35(46.05 \%)$ \\
\cline { 2 - 3 } & Bilateral & $3(3.95 \%)$ \\
\hline \multirow{2}{*}{$\begin{array}{l}\text { Occurrence of indirect } \\
\text { inguinal hernia }\end{array}$} & Primary & $70(92.1 \%)$ \\
\cline { 2 - 3 } & Recurrent & $6(7.9 \%)$ \\
\hline
\end{tabular}

Table 3. Complications of 'plug free' PHS hernioplasty (total 76 hernias)

\begin{tabular}{|l|l|l|}
\hline Complication & Seroma & Number \\
\hline $\begin{array}{l}\text { Early } \\
\text { postoperative } \\
\text { (30 days) }\end{array}$ & Early postoperative pain & $1(1.32 \%)$ \\
\hline $\begin{array}{l}\text { Late } \\
\text { postoperative }\end{array}$ & $\begin{array}{l}\text { Chronic pain } \\
\text { (up to 6 months) }\end{array}$ & $1(1.32 \%)$ \\
\cline { 2 - 3 } & Recurrence & $1(1.32 \%)$ \\
\cline { 2 - 3 } & Extraction of PHS mesh & $1(1.32 \%)$ \\
\hline
\end{tabular}

PHS $=$ Prolen Hernia System ${ }^{\circledR}$

Chronic pain, which was observed in one patient, lasted for 5 months and was treated with orally administered NSAID. The pain resolved spontaneously. One patient experienced discomfort in the inguinal region and was examined by a hernia specialist and other experienced hernia surgeons who found no recurrence and suggested nonoperative treatment. The patient was operated in a military hospital and PHS was removed. Open hernioplasty was performed.

\section{Discussion}

After the first report (1999) and description of the new tension-free open technique for inguinal hernia, PHS hernioplasty (PHS, Ethicon ${ }^{\circledR}$ ) has become widespread in the domain of hernia surgery ${ }^{1}$. Today, PHS hernioplasty is suggested by various experts with a conclusion of low recurrence and chronic pain (Level 1A) and can be considered as an alternative treatment to the Lichtenstein repair (Level B) ${ }^{8}$. Three-dimensional bilayer patch device consists of an onlay and underlay patch connected with a connector which "remains in the internal ring or the direct defect"1. After the initial report, in 2004 Gilbert et al. provided statistics on complications. In 4801 repairs, they reported only "two patients with chronic neuralgia", accounting for $0.04 \%$ in their paper'. Later, other researchers found higher incidence of chronic neuralgia or chronic pain after PHS hernioplasty: $0.7 \%, 1.6 \%, 1.8 \%$ to up to $3.2 \%$ and even more in a smaller number of patients ${ }^{3,10-12}$. 'Plug in' PHS hernioplasty is not the only procedure that results in chronic pain, since other plug and patch techniques also result in chronic pain in approximately $3 \%{ }^{13}$. The position of the PHS connector in internal hernia ring and lateral position of spermatic cord through onlay patch after placement of underlay patch could be an important factor in 'squeezing' the nerves in the original technique ${ }^{14,15}$. Another problem with putting the PHS connector and underlay patch through internal hernia ring is damage to parietal peritoneum and the possibility of direct contact with small or large intestine, which could lead to damage to the intestinal wall and septic complication ${ }^{16,17}$. In our placement modification, by moving the PHS connector 'lower' or medially in Hesselbach triangle through separate opening of transverse fascia we eliminate the possibility of 'squeezing' the nerves and spermatic cord in internal ring, and avoid direct contact with peritoneal contents of underlay patch alone or together with the connector. In our series of 76 'no plug' PHS hernioplasties, there was only one (1.32\%) 
patient with chronic pain and none suffering damage to the intestinal wall. Our technique of opening onlay patch in $\mathrm{Y}$ fashion for spermatic cord and nerves is sufficient for adaptable passing for this structure. This opening resembles the Lichtenstein mesh repair (LMS). In a study that compared PHS and LMS, PHS had better results regarding chronic pain ${ }^{11}$. We take particular care not to take iliohypogastric nerve in suture during fixation of onlay patch. There were no displacements of PHS mesh as we fixed with Prolen sutures. On the other hand, underlay patch is quite sufficient to overlay the entire region and all the weak points to prevent recurrence. In our series, we had only one $(1.32 \%)$ recurrence, while other studies with PHS hernioplasty report recurrence rate from 0 to $2.3 \% \%^{10,18,19}$. In one patient with recurrent inguinal hernia after 'plug free' PHS hernioplasty, in reoperation we found enlargement of internal inguinal ring, which was not covered by onlay patch. We simply put two sutures over internal ring, with good clinical result years after the operation. There were no reasons to extract the PHS bilayer patch device in recurrent hernia.

Discomfort of PHS is a well-known event. In one research conducted 5 years after PHS hernioplasty, about $20 \%$ of patients reported discomfort ${ }^{20}$. In our series, we found only one (1.32\%) patient with discomfort, which led to the extraction of the bilayer patch device in another hospital. In this case we do not have data on the exact reason for extraction or intraoperative complication, but we have data on good clinical outcome.

\section{Conclusion}

The technique for placement modification of the bilayer patch device for indirect inguinal hernioplasty is a safe procedure in low volume hernioplasty hospitals, with a low rate of recurrence and chronic pain at long term.

\section{References}

1. Gilbert AI, Graham MF, Voigt WJ. A bilayer patch device for inguinal hernia repair. Hernia. 1999;3:161-6. DOI: 10.1007/ BF01195319

2. Gilbert AI, Graham MF, Voigt WJ. The lateral triangle of the groin. Hernia. 2000;4:234-7. DOI: 10.1007/BF01201073

3. Mayagoitia JC, Prieto-Díaz Chávez E, Suárez D, Cisneros $\mathrm{HA}$, Tene CE. Predictive factors comparison of complications and recurrences in three tension-free herniorrhaphy techniques. Hernia. 2006;10(2):147-51. DOI: 10.1007/s10029005-0057-z

4. Berende CA, Ruurda JP, Hazenberg CE, Olsman JG, van Geffen HJ. Inguinal hernia treatment with the Prolene Hernia System in a Dutch regional training hospital. Hernia. 2007; 11(4):303-6. DOI: 10.1007/s10029-007-0218-3

5. Zuvela M, Krivokapic Z, Galun D, Markovic V. Rare late mesh complications following inguinal Prolene Hernia System hernioplasty: report of three cases. Surg Today. 2012;42:1253-8. DOI: $10.1007 / \mathrm{s} 00595-012-0189-6$

6. Chen MJ, Tian YF. Intraperitoneal migration of a mesh plug with a small intestinal perforation: report of a case. Surg Today. 2010;40(6):566-8. DOI: 10.1007/s00595-009-4107-5

7. Lichtenstein IL, Shulman AG, Amid PK, Montllor MM. The tension free hernioplasty. Am J Surg. 1989;157(2):188-93. PMID: 2916733

8. Miserez M, Peeters E, Aufenacker T, Bouillot JL, Campanelli $\mathrm{G}$, Conze J, et al. Update with level 1 studies of the European Hernia Society guidelines on the treatment of inguinal hernia in adult patients. Hernia. 2014;18(2):151-63. DOI: 10.1007/ s10029-014-1236-6

9. Gilbert AI, Young J, Graham MF, Divilio LT, Patel B. Combined anterior and posterior inguinal hernia repair: intermediate recurrence rates with three groups of surgeons. Hernia. 2004;8:203-7. DOI: 10.1007/s10029-004-0238-1

10. Faraj D, Ruurda JP, Olsman JG, van Geffen HJ. Five-year results of inguinal hernia treatment with the Prolene Hernia System in a regional training hospital. Hernia. 2010;14(2):155-8. DOI: 10.1007/s10029-009-0576-0

11. Awad SS, Yallampalli S, Srour AM, Bellows CF, Albo D, Berger DH. Improved outcomes with the Prolene Hernia System mesh compared with the time-honored Lichtenstein onlay mesh repair for inguinal hernia repair. Am J Surg. 2007; 193(6):697-701. DOI: http://dx.doi.org/10.1016/j.amjsurg.2006.08.087

12. Gohel J, Patel U. Prolene Hernia System in the tension-free repair of primary inguinal hernias. Natl J Med Res. 2012; 2(3):302-5.

13. Dalenbäck J, Andersson C, Anesten B, Björck S, Eklund S, Magnusson O, et al. Prolene Hernia System, Lichtenstein mesh and plug-and-patch for primary inguinal hernia repair: 3-year outcome of a prospective randomised controlled trial. The BOOP study: bi-layer and connector, on-lay, and on-lay with plug for inguinal hernia repair. Hernia. 2009;13(2):121-9. DOI 10.1007/s10029-008-0443-4

14. Hirose T, Takayama Y, Komatsu S, Shingu Y, Sakamoto E, Norimizu S, et al. Randomized clinical trial comparing lightweight or heavyweight mesh for mesh plug repair of primary inguinal hernia. Hernia. 2014;18(2):213-9. DOI: 10.1007/ s10029-013-1105-8

15. Doerhoff C. Synthetic bioabsorbable hernia plug for plug and patch inguinal herniorrhaphy implantation technique. Surg Technol Int. 2012;22:121-4. PMID: 23109070 
16. Lo DJ, Bilimoria KY, Pugh CM. Bowel complications after Prolene Hernia System (PHS) repair: a case report and review of the literature. Hernia. 2008;12(4):437-40. DOI: 10.1007/ s10029-008-0338-4

17. Wijers O, Conijn A, Wiese H, Sjer M. Appendico-cutaneous fistula 20 years after groin hernia repair with a polypropylene plug. BMJ Case Rep. 2013;2013.

18. Mayagoitia JC. Inguinal hernioplasty with the Prolene Hernia System. Hernia. 2004;8(1):64-6. doi:10.1136/bcr-2013-009801
19. Huang CS, Huang CC, Lien HH. Prolene Hernia System compared with mesh plug technique: a prospective study of short- to mid-term outcomes in primary groin hernia repair. Hernia. 2005;9(2):167-71. DOI: 10.1007/s10029-005-0318-x

20. Pierides G, Vironen J. A prospective randomized clinical trial comparing the Prolene Hernia System ${ }^{\circledR}$ and the Lichtenstein patch technique for inguinal hernia repair in long term: 2- and 5-year results. Am J Surg. 2011;202(2):188-93. DOI: http://dx.doi.org/10.1016/j.amjsurg.2010.06.027

Sažetak

\section{“NEZAČEPLJUJUĆA” MODIFIKACIJA POZICIJE KONEKTORA DVOSLOJNE PROLENSKE MREŽICE U HERNIOPLASTICI MUŠKE INGVINALNE HERNIJE}

\section{D. Ilici i S. S. Putnik}

Dvoslojna mrežica (Ethicon, Prolen Hernia System ${ }^{\circledR}, \mathrm{PHS}^{\circledR}$ ) za reparaciju preponskih kila sadrži konektor koji ima ulogu "čepa" u unutarnjem preponskom prstenu. Pozicija ove "čep" komponente može biti odgovorna za kroničnu bol i oštećenja crijeva. Pretpostavili smo da će promjena položaja konektora dvoslojne mrežice (PHS $\left.{ }^{\circledR}\right)$ i njegovo postavljanje medijalno u Hesselbachovu trokutu doprinijeti manjoj učestalosti kronične boli i da neće doći do oštećenja crijeva, s dobrim kliničkim ishodom nakon reparacije indirektne preponske kile. Ova retrospektivna studija je obuhvatila 73 bolesnika sa 76 indirektnih preponskih kila kod kojih je u razdoblju od 2005. do 2015. napravljena modifikacija postavljanja dvoslojne mrežice. Prosječna starost bolesnika bila je 57 godina. Tri bolesnika su imali rane poslijeoperacijske komplikacije (3,95\%), dva serom i jedan ranu poslijeoperacijsku bol. Tri (3,95\%) bolesnika su imali kasne poslijeoperacijske komplikacije: jedan $(1,32 \%)$ s kroničnom boli, jedan $(1,32 \%)$ s recidivom i jedan $(1,32 \%)$ s ekstrakcijom mrežice zbog nepodnošenja. "Nezačepljujuća" pozicija konektora dvoslojne mrežice kod bolesnika s indirektnim ingvinalnim hernioplastikama je siguran postupak s niskim postotkom kronične boli, bez oštećenja crijeva i sa standardno malim brojem recidiva.

Ključne riječi: Dvoslojna mrežica; Konektor; Indirektna hernioplastika; Recidiv; Kronična bol 